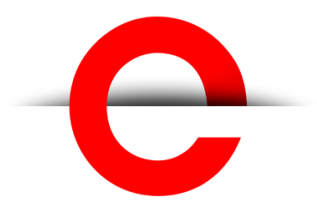

U T S

e P R E S S

International Journal

of Rural Law and

Policy

No. 2, 2019
ARTICLE (NON-REFEREED)

\section{Rural crime and law}

\section{Christopher J Bone}

Retired magistrate (NSW, Australia). cbo68634abigpond.net.au

DOI: https://doi.org/10.5130/ijrlp.2.2019.6554

Article History: Received 09/04/2019; Revised 16/06/2019; Accepted 28/06/2019.

Published 06/08/2019

\section{ABSTRACT}

This paper discusses the nature and extent of rural crime and suggested solutions to rural crime; providing the author's opinion on mandatory sentencing, increased penalties, certainty of detection, and reduction of the profit motive. Particularly, the article discusses the issues of stock theft, abalone poaching, firearms offences, traffic offences, logging protest cases, pastures protection - legal principles, proposed solutions, practical issues. The article also touches on changes in law enforcement, technology and the administration of justice, as well as police interviews with suspects, DNA, video surveillance, domestic violence issues and women in courts.

The paper concludes with a description of the experiences of a magistrate who lived and worked in rural NSW, discussing issues that arise as a result of inevitable relationships with accused and others in the town.

\section{Keywords}

rural magistrates; stock theft; abalone poaching; firearms offences; logging protests; mandatory sentencing

\section{Introduction}

In July 1984, I was appointed a magistrate of what became the Local Court of New South Wales (NSW) on 1 January 1985. After spending about six months in Sydney , I became the circuit magistrate at Inverell and, thereafter, sat exclusively in courts in rural areas until my retirement in 2015 .

The primary purpose of this paper is to provide material relating to my experiences in dealing with rural crime and to look at practices which have been suggested as possible
1
DECLARATION OF CONFLICTING INTEREST The author(s) declared no potential conflicts of interest with respect to the research, authorship, and/or publication of this article. FUNDING The author(s) received no financial support for the research, authorship, and/or publication of this article. 
U T S

e PRES S solutions to the prevalence of rural crime. The practices to which I refer are (i) mandatory sentencing, (ii) the availability and imposition of significant sentences, (iii) certainty of detection and (iv) removal of the profit motive. I will say something about those practices before turning to specific areas of rural crime. A secondary purpose of the paper is to outline aspects of life as a Magistrate in a rural area.

It has been the policy of Chief Magistrates to advise those seeking appointment to the Local Court bench that they will be required to spend a minimum of two years on a rural circuit. Most circuit Magistrates reside within the boundaries of the circuit. Almost all Magistrates undergo rural service and most consider, after spending time in 'the bush', that such service enriched their life and their career. I went to Inverell with my young family never having lived outside of Sydney. I had little or no knowledge of matters related to farming and grazing. The subject of most cases which I heard on the circuit was the familiar traditional fare of every Local Court from Waverley to Wilcannia, including traffic offences, matters of violence, matters of dishonesty and domestic violence. Drug offences were not as common in the outposts of the empire as in the metropolitan areas but there was no shortage of them in the bigger rural towns. There were, however, many cases I heard which would never come before a court in the big cities.

Some were relatively minor and not particularly prevalent, such as prosecutions of people who: would not move stock the required distance when on stock routes; did not do enough to suppress rabbits or blackberries; and operated small scale illegal abattoirs. Two categories of offences which I encountered which were common, which could be very serious and which had either entirely or substantially a rural flavour related to stock theft and abalone poaching. Stock theft is solely a rural crime and it is probably the quintessential rural crime. I heard about 40 stock theft cases and almost all were hotly contested. Breaches of laws relating to abalone are not widespread - in this state only on the south coast - but such offences commonly appear on the lists in all courts between Nowra and the Victorian border. Other offences which occur both in the cities and in the country but which often require a different approach when committed in the country are those relating to firearms and to traffic. I also heard several cases involving what might be called environmental protest cases involving the logging industry.

There are limitations upon a Magistrate of the Local Court sitting in the criminal jurisdiction. Usually, the Magistrate must ascertain whether an accused person is guilty and, if so, the Magistrate is then required to sentence the accused person. The maximum penalty which a Magistrate may impose for a single offence is two years imprisonment (provided the maximum penalty for the specific offence is two years or more). A higher sentence may be imposed when sentencing an accused person guilty of multiple offences, five years being the maximum. Such cases are said to have been heard on a summary basis. In a small percentage of cases, the Magistrate commits the accused person to the District Court or the Supreme Court for trial or sentence. Such cases are then heard on indictment.

\section{The extent of crime}

It is impossible to assess how many people commit crime - although the majority of people in Australia do not commit crime, rural or otherwise. There are two reasons for this inability to know how many people are criminals: first, what is crime, and second, not all crime is reported. In theory, any activity which can attract a penalty imposed by the state is a crime. The community, however, is unlikely to regard minor traffic offences and many of the regulatory 
U T S

e PRES S

offences as crimes. The Australian Bureau of Statistics reported that approximately 414,000 people were arrested by police in Australia in a 12-month period during 2016/17. This represented 2 per cent of the population, up marginally from 1.98 per cent in the previous 12 months.

It is trite to say that much crime cannot be prevented. A significant proportion of the people who appeared before me were addicted to alcohol or illicit drugs, were raised in dysfunctional circumstances or suffered from mental illness. Crimes of passion and crimes committed when the offender is under the influence of alcohol or an illicit drug are, in practical terms, very difficult or impossible to prevent.

Crime has always been a part of life and virtually everything imaginable has been done to come to grips with it. People have been executed - sometimes in the most grisly manner - imprisoned, exiled, maimed, beaten and deprived of assets, and yet crime is a constant. We are continually searching for ways to combat crime and I will now turn to some initiatives put forward in that search.

\section{Practices which might prevent or reduce crime}

\section{MANDATORY SENTENCING}

There are occasionally calls for mandatory sentencing to be introduced as a crime prevention measure. Mandatory sentencing is a sentencing practice whereby a judicial officer must impose a minimum sentence for a particular crime. Limited mandatory sentencing has existed in NSW at different times. Until 1953, the only sentence which a Judge could impose upon a person convicted of murder was the death penalty (the last execution took place in 1939). After the death penalty was abolished and until 1989, the only sentence a Judge could impose upon a person convicted of murder was life imprisonment (the executive government could release a convicted murderer on licence). The effect of legislation enacted in 1989 was to abolish the mandatory minimum sentence of life imprisonment in respect of murder convictions.

In 2014, the NSW Parliament created the offence of assault causing death and enacted a minimum sentence of eight years for the crime (see ss 25A and 25B Crimes Act 1900 (NSW)). This is generally called the 'one punch law'. Some have argued that the minimum period of licence disqualification which must be imposed following a conviction for a range of traffic offences is an example of mandatory minimum sentencing but it is generally accepted that the disqualification is ancillary to the sentence rather than part of it.

It is not well known that a regime of widespread mandatory sentencing existed in NSW in 1883/84. ${ }^{1}$ Most offences in those days fell into six sentencing categories: death, life imprisonment and imprisonment for 14, 10, seven and five years. Legislation was passed which required a judicial officer to impose a minimum sentence regarding all categories except the death sentence. The minimum sentence to be imposed was seven years for offences which carried a maximum of life imprisonment, five years for offences carrying a maximum of 14 years, three years for offences carrying a maximum of 10 years, two years for offences carrying a maximum of 7 years and twelve months for offences carrying a maximum of five years. The legislation was not enacted capriciously. It had been widely debated for three years and

\footnotetext{
1 See the excellent account of the experiment in GD Woods, A History of Criminal Law in New South Wales: The Colonial Period 1788-1900 (Federation Press, vol 1, 2002).
} 
U T S

e PRES S

received substantial public support. It lasted just 13 months before its unlamented repeal. It had not worked: Judges had had to impose too many patently unfair sentences.

The major argument in favour of mandatory minimum sentencing is that it eliminates manifestly weak sentences. The major argument against it is that it eliminates (or greatly reduces) the use of discretion by a judicial officer. It is a matter of debate on the extent to which offenders receive manifestly weak sentences. I maintain there are reasons to indicate that manifestly weak sentences are uncommon.

The appeal process: The appeal process that exists in NSW reduces the prospect of a manifestly weak sentence imposed at first instance remaining in force. The process is outlined in sections 11-27 of Crimes (Appeal and Review) Act 2001 (NSW) and can be briefly outlined as follows. With sentences imposed by the District and Supreme Courts, both the Crown and the accused may appeal against a sentence considered inappropriate and, with sentences imposed in the Local Court, both the prosecutor and the accused have a similar right.

Bail statistics: Judicial officers should approach all of their tasks, including sentencing, by adhering to well-established principles. They should know that because of their background as lawyers, their training and experience. That they do so is to be found by a reference to bail decisions. At the end of 2014, there were 3,083 people on remand in NSW. Three weeks later, amendments to the Bail Act 2001 (NSW) came into law and it became much more difficult for offenders charged with offences other than minor ones to obtain bail. At the end of 2017 there were 4,447 people on remand. That represents an increase of 1,364 persons or 44.2 per cent. Although there was an increase in the number of people brought before the Local Court in that three-year period, it was only 13.8 per cent. Magistrates had clearly demonstrated a tougher approach to bail by applying the tougher laws. A manifestly weak sentence will only be imposed by a judicial officer who has not followed the proper principles because of misplaced compassion for an offender. It is likely that such a judicial officer would also fail to follow proper principles in relation to matters of bail. The evidence, however, indicates that the Magistrates, by refusing bail a lot more after the amendments to the Bail Act, were doing exactly what they were supposed to do.

\section{SIGNIFICANT SENTENCES}

Occasionally, after a serious offence has been committed, there will be calls for the maximum sentence to be increased for the offence. In September 2018, the strawberry industry was dealt a devastating blow when small needles were discovered in several strawberries for sale at supermarkets. The Prime Minister was reported as foreshadowing an increase in the maximum penalty for such an offence (see s 380 Criminal Code Act 1995 (Cth)) to 15 years. Would such an increase be likely to affect the frequency of offences of this nature?

The most significant sentence that can be imposed is the death penalty. The only 'Western democracy' that, for practical purposes, has retained the death penalty is the US. Many studies indicate that the death penalty is not an effective deterrent to potential offenders. ${ }^{2}$ Most studies in relation to the deterrent effect of the death penalty are based upon the sentence being imposed for an offence of murder, generally a crime which involves little lengthy premeditation. Statistics from countries which impose the death penalty for offences which generally have a degree of lengthy premeditation are inconclusive, but it is a matter of 
U T S

e PRES S notoriety that people who commit the crime of drug trafficking in several Asian democracies continue to be executed despite the argument that if the death penalty was a real deterrent, the first execution for such a crime would have been the last (16 people were executed for drug trafficking in Indonesia in 2015).

\section{Increased penalties versus high prospect of apprehension (certainty of detection)}

Powerful lessons relating to crime prevention may be learned from the annual death rate on NSW roads in the last 40 years. Table 1 summarises the road toll in NSW:

Table $1 \quad$ NSW Road toll 1982-2017

\begin{tabular}{|l|l|l|}
\hline \multicolumn{1}{|c|}{ Year } & \multicolumn{1}{|c|}{ Deaths } & \multicolumn{1}{|c|}{$\begin{array}{c}\text { Fatalities } \\
\text { (per 100,000) }\end{array}$} \\
\hline $1982^{*}$ & 1253 & 23.6 \\
\hline 1983 & 966 & 18.0 \\
\hline 1992 & 649 & 10.9 \\
\hline $1995^{* *}$ & 620 & 10.2 \\
\hline 1997 & 576 & 9.2 \\
\hline 2002 & 561 & 8.5 \\
\hline 2012 & 369 & 5.1 \\
\hline 2017 & 392 & 4.9 \\
\hline
\end{tabular}

* Random breath testing introduced in December 1982

** Penalties doubled in 1996

(Source: NSW Centre for Road Safety, Road Crash Fatality Rates, 1908-2013)

The highest number of deaths recorded on NSW roads in a calendar year was 1,384 in 1978. The road toll in NSW in 2018 was 353, the lowest figure since 1925. Governments have done a lot to address the dreadful carnage of the 1970s. Cars are safer, roads are better designed, cyclists wear helmets, maximum speed limits have been reduced and safety belts and child restraints have become compulsory. The statistics shown in Table 1, however, indicate that introducing random breath testing had more impact on the road toll than any other measure: the road toll dropped by a quarter in 12 months; the impact was immediate. People who had regularly consumed alcohol and driven no longer did so. The only logical conclusion to be drawn is that motorists were concerned about the heightened prospect of apprehension if they drove with alcohol in their system. By contrast, in 1996 there was a doubling of both maximum penalties and minimum periods of licence disqualification for serious driving offences; there was little or no impact on the road toll. 
U T S

e PRES S

\section{REDUCING OR ELIMINATING THE PROFIT MOTIVE}

Offenders who have committed crimes of dishonesty commonly appear before the courts. Drabsch $^{3}$ reports that theft and related offences represented 17.6 per cent of the crime committed in the state. Like most crime, offences of dishonesty come in a wide range of circumstances. I dealt with thousands of cases of dishonesty in my career as a solicitor and magistrate. Many offences were committed by people under the influence of alcohol or an illicit drug, and many were spontaneous crimes of opportunity. Some crimes of dishonesty, however, are carefully planned and, if successfully completed, can provide rich returns for offenders. Any practice which has the potential to reduce or eliminate illegal gains is likely to deter a criminal whose only interest is unlawful personal enrichment.

\section{Rural crime}

Rural crime can be defined in several ways. A specific definition is not important for many who have an interest in the subject but it is important if a concerted effort is to be made to address it. Stock theft would be accepted by one and all as a rural crime but what about breaking, entering and stealing from a farm property? Such a crime would not be a rural crime if the thief stole money; it would, however, if the thief stole hay or farming equipment. The importance of a definition rests upon law enforcement agencies employing people with specialised qualities when addressing certain crimes. The Police Force, for example, uses specialised Rural Crime Investigators in certain areas of its operations. The efficiency of this group of officers will be much reduced if they are called upon to investigate offences which have no rural flavour other than they have taken place in a rural area.

\section{STOCK THEFT}

The statutory provisions generally utilised in relation to stock theft are at section 126 and following of Crimes Act 1900 (NSW). Section 126 states that 'Whosever steals any cattle ... shall be liable to imprisonment for fourteen years'. The First Fleet brought four cows, six horses, five rabbits, 32 pigs, 19 goats, 44 sheep and 87 chickens to Sydney. This was a modest beginning but when the soldiers and free settlers learned of the rich pastures in the colony, cattle and sheep arrived in abundance. Australia's grazing industry was well established by the second decade of the $19^{\text {th }}$ Century. Most stock theft by white people in the early days of the colony was carried out for survival or a change of diet. Convicts, including absconders, stole and ate stock. Aboriginal people also took stock. On occasions, taking stock by Aboriginal people was regarded as a form of 'rent' for the unwelcome use by the white man of traditional lands and, occasionally, as a means of deterrence against white settlement. As time passed, the motive for stock theft became almost invariably mercenary.

Stock theft reached epidemic proportions in the $19^{\text {th }}$ Century. The story of Ned Kelly is well known to most Australians. He is seen by some as a man driven to murder by persecution from the police. The true position is more complex. By the time Ned Kelly was born, sheep, cattle and horses grazed throughout Victoria. There was animosity between many small landholders and many owners or occupants of larger properties. Cattle duffing was prevalent and members of the Kelly family were enthusiastic participants. Organisations were formed to suppress stock theft, such as the Moyhu Stock Protection Society, which made a presentation to one of the

3 Talina Drabsch, A Statistical Snapshot of Crime and Justice in New South Wales (NSW Parliamentary Library Research Centre, 2010). 
U T S

e PRES S police officers present at the Glenrowan Siege. The North East Stock Protection League was another significant organization. The stealing of cattle was relatively easy because of a lack of fencing, the small population, sympathy and sometimes admiration for the thieves, and the primitive nature of communications. These difficulties diminished over time and stock theft, although still a significant problem, is currently not as widespread as it was in the $19^{\text {th }}$ Century.

Stock theft today exists in two basic forms: The organized thief will plan a large-scale operation designed to remove large numbers of stock and transport them over large distances for immediate sale and the small-scale thief will take a few head generally for incorporating with his own stock. Examples of large-scale operations are:

- In 1989 three people received seven years imprisonment for stealing approximately 3,000 unbranded cattle from in Queensland. ${ }^{4}$

- In 2004 a Dubbo man was charged with stealing cattle worth about \$250,000. Many were taken from saleyards. ${ }^{5}$

- In 2012 eight hundred and sixty bullocks were stolen from a property near Tambo. They were tagged and branded. ${ }^{6}$

- In 2016 three people were charged with stealing 72 head of cattle from a property near Cunnamulla and taking them nearly $900 \mathrm{~km}$ to Harden. ${ }^{7}$

Serious offences are dealt with in the District Court. I encountered a handful of cases in which I committed alleged offenders for trial or sentence in that court. The overwhelming majority of cases which came before me involved a few stock. Two examples are:

- The accused and his wife owned and operated a grazing property on the Northern Tablelands. They had purchased it from the accused's father who maintained an active interest in the property after he retired, visiting it regularly to work there. The accused and his wife each played an active role in running the property and each had a second job in a nearby town. They had between eight and nine hundred sheep and some cattle. Their neighbour also had sheep. Nine of his sheep were on the accused's property. They bore the neighbour's ear markings and the accused's paint brand. There was considerable disputed evidence on whether the paint brands represented a crude attempt by the neighbour to 'set up' the accused whom he believed had stolen sheep in the past. I was satisfied that the sheep had been stolen. The accused, his wife and the accused's father each denied knowledge of the theft. The accused was a man of good character. This case was typical in three respects of the cases I encountered: there was no direct evidence that the accused had stolen the sheep, he had made no admissions and he was of good character. It was atypical in the sense I could be certain that the sheep had not strayed; the prosecution and defence agreed that the fences were stockproof. The case was one of circumstantial evidence. ${ }^{8}$ The accused may well have committed the offence but so may the accused's wife or father.

- The accused owned and operated a grazing property in a relatively isolated part of the Northern Tablelands. An adjoining property was also a grazing property. The fences

4 'Long Complex Investigation Leads to Cattle Duffing', (Courier-Mail 25 May 2012

5 Tanya Nolan, 'Cattle-Duffing Ring Uncovered, PM (ABC Radio National, 25 June 2004).

6 'Grazier Says Cattle Duffing Case Misleading', ABC News (ABC TV, 15 August 2012).

7 'Charges Made for Cattle Theft', The Land (7 April 2016).

8 See Chamberlain v R (1984) 58 ALJR 133 
U T S

e PRES S

were difficult to maintain and there was a history of cattle straying. The accused and his neighbour had originally been on good terms. Each had occasionally found one or two head of cattle on the other property and arrangements were made to return them. The relationship deteriorated, however, and the neighbour reported a theft of two cows to the police and two of his cows were found on the accused's property. The neighbour maintained that he and the accused had had a conversation a week after the search in which the accused admitted the theft. Police sought to interview the accused about that conversation but he maintained his right to silence. He gave evidence in which he admitted he and his neighbour had had a heated conversation but he denied the alleged admission. I could not accept beyond reasonable doubt that the neighbour's account of the conversation was to be accepted. Again, a case in which the law relating to circumstantial evidence loomed large.

Statistics from the Bureau of Crime Statistics and Research indicate that 82 per cent of those accused of a crime pleaded guilty in 2012. ${ }^{9}$ These statistics accord with my experience. About four people out of every five who came before me pleaded guilty but I encountered very few pleas of guilty in the stock theft cases which I heard. They were cases in which the doctrine of recent possession and the principles relating to cases of circumstantial evidence were important. The identity of the stock was occasionally an issue. Most of my stock theft cases came from the Northern Tablelands, a rugged region in which it is somewhat difficult to maintain stockproof fences.

Interviews with primary producers and the bodies that represent them suggest that many victims of stock theft do not report the crime, indicating that it is not worth the trouble and an insufficient penalty will be given if the culprit is apprehended and convicted. I would be surprised to find that large-scale thefts were not reported. A large-scale theft can bankrupt a victim. In addition, a criminal who engages in such an operation will, if apprehended, have little chance of avoiding a conviction and a significant sentence of imprisonment. The apprehended thief will either be caught in the act or on the road in a truck full of stolen cattle or at a saleyard with a lot of stolen stock. Guilt would not be difficult to establish. It is the small-scale theft which will probably not be reported. A thief who has no prior convictions and who is convicted of stealing a few sheep or cows is not likely to go to gaol. The theft, in isolation, will concern and annoy the victim but it will not bankrupt him or her. Small-scale stock theft, however, can have a significant cumulative effect upon a victim. A few stolen today, a couple in six months etc, can add up. It may be tempting for a victim of a small-scale theft not to report the matter but I am confident that failure to do so may well encourage the thief to repeat the exercise.

Solution to large scale stock theft: I imagine, without ever having been on the land myself, that it would be relatively easy to steal a lot of cattle or sheep. A truck, some bolt cutters and a few people with stock-handling experience should be able to steal many animals from a property in the right circumstances. Offenders committing such a crime would then wish to move the stock as far from the scene of the crime and sell the stolen animals as soon as possible. The thing above all others which would deter such offenders is an elimination or substantial reduction of the offenders' opportunity to profit from the crime.

A system which could achieve that might operate as follows. First, stock would be electronically identified and branded. Second, the owner of stolen stock would advise a

9 NSW Bureau of Crime Statistics and Research, Issue Paper 96 (August 2014). 
U T S

e PRES S

national Registry of the theft. Third, the Registry would advise all stock agents and saleyards of the theft. Fourth, all stock agents would have to identify stock which they were selling to ensure that they were not listed as stolen, such identification to be conducted through the electronic identification device. Fifth, the Registry would be available to anyone purchasing stock privately. With the system would be a legislative regime giving certain police officers the right to randomly stop cattle trucks and inspect and scan stock in these trucks. I understand that under the National Livestock Identification System (NLIS), cattle and sheep are tagged with electronic ear devices. I further understand that (a) these devices can be removed and/ or replaced by experienced people and (b) internal devices are not inserted into cattle and sheep because abattoirs will not take livestock with internal devices. The NLIS was introduced primarily to eliminate biosecurity and health risks. If a way could be found to introduce a secure device into livestock, the system which I have outlined could be used to much reduce or even eliminate large-scale theft.

\section{ABALONE POACHING}

Offences in relation to abalone are prolific on the south coast of NSW. Such offences may not immediately come to mind as classic rural crime but all offences, as far as I know, are committed between the Victorian border and Wollongong. In the six years in which I was the South Coast circuit Magistrate, I sat at courts from Batemans Bay in the north to Eden in the south. Offences involving abalone came before me regularly.

All I knew about abalone before I went to Batemans Bay was that it was a popular seafood and that prosecutions relating to it were common on the South Coast and Nowra circuits. The Report on Illegal Fishing for Commercial Gain or Profit in NSW commissioned by the Minister for Agriculture and Fisheries and presented to government in 2004 (the Palmer Report) ${ }^{10}$ provided me with interesting material. The report stated that the legal annual commercial harvest was 281 tonnes per annum. There were small legal and illegal non-commercial harvests and an extraordinarily large illegal commercial harvest. The illegal commercial harvest was estimated by some sources within the industry as being more than the legal harvest. The report indicated there was substantial evidence to conclude that there was a widespread black market trading in abalone and a significant illegal export industry, much of the illegal harvest believed to be of undersized abalone. The report also indicated that illegal activity represented a serious threat to the existence of abalone and directly competed against commercial operators whose activities were stringently policed and who had expended a lot of money to operate.

As I heard cases involving abalone several things became very clear:

1. The offences fell into two main classes. First, there was possession of excess numbers. The bag limit for a non-commercial operation was 10 per person (later reduced to two) and offenders had numbers ranging from a couple above the limit to nearly 1,000 above the limit. Second, most of the unlawfully possessed abalone were under the permissible size.

2. The maximum penalties available were low. A magistrate's opinion of a law, including any penalty that might be imposed, is a private matter and is not something upon which a magistrate should comment publicly. The matters which came before me

10 Mick Palmer, Report on illegal fishing for commercial gain or profit in NSW (Department of Primary Industries, 2004) (Palmer Report) <http://www.fisheries.nsw.gov.au/com/pdf/Black-Market-Report.pdf> 
U T S

e PRES S

involved summary offences and the maximum penalty was three months (there was no provision to take cases on indictment). The effective maximum penalty, assuming a plea of guilty was entered and a sentence discount given, was nine weeks. This was usually adequate but inadequate in a case involving an offender who possessed hundreds of abalone and particularly so if the accused had prior convictions for similar offences. I wrote to the Chief Magistrate about my concerns and he passed my correspondence on to the appropriate authority with his endorsement. The legislation governing these offences was substantially reviewed in 2010. Because of that review, there were legislative changes and offences can now be prosecuted on indictment, the maximum penalty in such cases being 10 years imprisonment.

3. A surprisingly large number of the offenders who appeared before me charged with possessing large numbers of abalone were residents of Victoria. I cannot refer to statistics and so this is only a personal recollection but is a strong recollection. There is more abalone in the southern states than in NSW. The penalties which could be imposed in those states when I was dealing with theses offences were much higher than in NSW. It is interesting to note that substantial terms of imprisonment are imposed for abalone and other fishing offences in southern states. ${ }^{11}$

4. An inordinate number of Aboriginal persons appeared. Abalone is a popular food in the indigenous community of the south coast and permits may be obtained to gather abalone over the usual limit in certain circumstances. Many offences committed by Indigenous offenders were offences at the bottom end of the range in terms of seriousness; possession of a few abalone over the limit. Others were occasionally the subject of a claim of Native Title. A relatively recent case involving a Native Title defence in relation to abalone offences is Dudley $\mathcal{G}$ Ors $v$ Dept of Primary Industries and Regions $\mathcal{E}$ Anor. ${ }^{12}$ Five Aboriginal persons had 370 abalone and raised a claim of Native Title under s 211 of the Native Title Act 1993 (Cth). The defence was unsuccessful in the Magistrates' Court of South Australia and, on appeal, in the Supreme Court of South Australia. Issues relating to both Native Title and sentences are considered in the judgement. States have attempted to abolish Native Title claims through legislation but without success. ${ }^{13}$

I was a member of the Judicial Commission's Ngara Yura group, which spent a weekend with the Aboriginal community at Wallaga Lake on the south coast. The Ngara Yura programme enabled judicial officers to attend Indigenous communities throughout the state. Many judges and magistrates have utilised the programme. It was interesting to hear various opinions expressed in relation to abalone offences. Some people expressed the view that Native Title principles should apply to all taking of abalone by Aboriginal people. Others expressed the view that limits had to be imposed if the seafood was to be available for future generations. Others expressed the view it had always been the custom to take abalone for consumption by oneself, family and friends but never for sale.

Solution to large scale abalone poaching: the increases in the penalties for these offences was long overdue. I am certain that some offenders came from southern states to poach abalone knowing that, if apprehended, their punishment would be much lighter than for the same

11 See DPP v MS DC of VIC (20.2.2015); DPP v Van Nguyen DC of VIC (12.4.2016).

12 (2016) SASC 144

13 See Karpany and anor v Dietman (2013) HCA 47. 
U T S

e PRES S offence committed in their home state. The best way to reduce the incidence now that that anomaly has been eliminated is to increase the chances of detection. Fisheries officers investigating poaching have significant expertise but offenders often operate in isolated areas and can be difficult to apprehend.

Maybe greater concentration upon the 'end user' might be productive. The Palmer Report concluded that most of the abalone taken in large scale illegal operations ended up in the capital cities and overseas. If investigating authorities could ascertain the detail of these end users, further inroads could be made into the illegal activities.

\section{FIREARMS OFFENCES}

Most firearms offences are dealt with under the Firearms Act 1996 (NSW) with some under the Crimes Act 1900 (NSW). I encountered a few such offences when I worked in the metropolitan area but dealt with many alleged offenders in rural areas. Some cases were serious, the firearms being possessed or used for nefarious purposes. Occasionally, I encountered cases involving pistols or shortened firearms. ${ }^{14}$ The saying that familiarity breeds contempt applied to nearly all of the balance. Police fact sheets referred to firearms kept in cupboards or the back shed, firearms left in cars, firearms left loaded in easy reach of family members and firearms being carried in circumstances redolent with negligence. I recall a case in which a father and son went out to shoot rabbits. The father told his son to go behind a thicket of blackberries and make a lot of noise. The son did so and the father accidentally wounded him when he fired at rabbits coming out of the thicket. I dealt with people who had wounded themselves because they had not taken adequate precautions when carrying a firearm through a fence. The non-curial consequences in some cases could be significant. Conviction for some offences resulted in revocation of the offender's shooters licence. This could be devastating for a primary producer or a professional kangaroo shooter or some other person whose livelihood depended upon the possession of a shooters licence. It should also be noted that a licence must be revoked if an apprehended violence order is made against a person. ${ }^{15}$ Often, there is no doubt that this is the most appropriate action. Sometimes, however, it can lead to an injustice if the person against whom the order is made uses a firearm as a tool of trade and the order is based upon behaviour which could not suggest that the person is a violent person.

\section{TRAFFIC OFFENCES}

The consequences of committing a serious traffic offence are more significant for a rural dweller than an urban dweller. Metropolitan areas have substantial public transport systems. Smaller rural areas do not. The Supreme Court of New South Wales has stated that a magistrate may properly reduce a period of disqualification if the effect of loss of licence upon an offender is unusually severe. ${ }^{16}$

14 See $R v$ Lachlan 2015 NSWCCA 178 for the seriousness of such offences.

15 Firearms Act 1996 (NSW) s 24.

16 See Guideline Judgement on High Range PCA 200461 NSWLR 305. 
U T S

e PRES S

\section{LOGGING PROTEST CASES}

There was, in my time as the circuit Magistrate at Batemans Bay, a small but particularly active group of people who disrupted logging activities on the far south coast of NSW. They mainly described themselves as environmentalists and their opponents mainly described them as greenies. It was their practice to prevent what they saw as illegal or inappropriate logging by many strategies, including the blockading of forest roads, sabotage of logging equipment and placing themselves in the canopy and at risk of death or injury if steps were taken to get them down. They also participated in protest activities.

An example of a case which had elements of both prevention and protest involved the activities of two men at the Eden chip mill. Logs are taken to the mill by various logging companies, the logs are then converted into chips and the chips are piled on a nearby wharf before being loaded onto boats. The site is surrounded by a high wire fence. The mill had closed for holidays in late 2010 and was due to resume operations on a Monday in January 2011. At about $4.30 \mathrm{am}$ on that day, two men entered the property and when the mill staff arrived for work they found each man chained by the neck to a piece of heavy machinery. The key to one padlock was easily found and that accused was unchained, arrested and taken away. The key to the second accused's padlock could not be found. Some other person, never identified, had taken the key away. The mill staff, police and rescue services took many hours to dismantle the machine and then take him, still chained to a small piece of the machine, to a place where specialised operatives could remove the chain with a circular saw.

The first accused gave evidence as follows. He was a 'forest activist' and had been to the far south coast in that capacity on several occasions. He had seen reports prepared by other activists indicating that a lot of the logging in the forests was illegal. He made his own observations which confirmed that view. He believed that most if not all the logs processed at the Eden chip mill had been illegally felled and so he disrupted the operation, his motivation being to protest about the unlawful taking of timber, to prevent the mill from making a profit from illegally obtained logs and to deter further unlawful logging. The second accused was a young interstate holiday maker who had met a few activists and played a role in the protest.

The hearing took place over two days. The first accused submitted he should not be convicted because there was insufficient evidence to establish that he actually hindered the mill staff in their operation and he believed that the mill did not have a legal right to conduct the activities taking place there because the raw material had been illegally taken. Each accused had been charged with trespass and with the offence of intimidation under section $545 \mathrm{~B}$ of the Crimes Act 1900 (NSW). That legislation was considered by the NSW Court of Criminal Appeal in $R v$ Keenan.17The elements of intimidation are a hindering of the other person in using his tools or other property and undertaking the activity to hinder the other person from doing something which the other person has a legal right to do; the prosecution must also establish that the accused's action was wrongful and without legal authority. The Court of Criminal Appeal held that the prosecution need not prove that the other person had the right to do the thing hindered but, if the evidence raises the issue, the prosecution must eliminate any reasonable possibility that the accused's purpose was to compel the other person to abstain from doing something which the accused honestly and reasonably believed that the person had no right to do.

17 (1994) 76 A Crim R 374. 
U T S

e PRES S

\section{PASTURES PROTECTION}

Landholders are occasionally charged with offences relating to an alleged failure to rid their properties of noxious animals or weeds. Section 126 of the Rural Lands Protection Act 1998 (NSW) requires the occupier of land to 'fully and continuously suppress and destroy by any lawful method all noxious animals that are on the land'. A virtually identical section of the Act's predecessor was considered by the Supreme Court of NSW in King $v$ Tait. ${ }^{18}$ The court held that the mere presence of a noxious animal was not of itself proof that the occupier had not met his or her obligations as rabbit destruction is a continuous operation. The intention of the legislation was to

[C]ast an obligation upon all occupiers of land to do everything which a reasonable man could reasonably be required or expected to do on the particular land in question for the purpose of destroying rabbits, applying and using current and approved methods for that purpose. The process must be carried out fully, that is thoroughly; and continuously, that is, in a manner characterized by continual effort having regard to the object to be achieved.

The court clarified that the test to be applied is objective and not subjective. That means that the obligation imposed upon the landholder is to do everything reasonably necessary to eliminate the problem, not the best that the occupier can do in his or her circumstances. For example, a physically disabled, cash-strapped occupier could not avoid responsibility by spending only as much as he or she could afford or doing as much suppression work as he or she could manage if such limited expenditure or work would not eliminate the problem.

\section{Life as a Magistrate in a rural area}

A few over 30 magistrates sit exclusively in courts outside the coastal strip extending from Newcastle to Wollongong and out to Penrith and Campbelltown. As mentioned, each person offered appointment as a magistrate is advised that he or she will almost certainly be required to accept a rural appointment at some stage in their career, and the overwhelming majority of Magistrates spend some time on country service. To a certain extent, life as a magistrate, whether in an urban or rural setting, is what the individual magistrate makes of it but guidance is given to all judges and magistrates. The Council of Chief Justices and Magistrates of Australia and New Zealand has published a Guide to Judicial Conduct which deals with issues relating to a judicial officer's behaviour both on and off the bench. ${ }^{19}$ The authors of the Guide accept there cannot be a code in relation to judicial behaviour but point out that the community expects judicial officers to behave according to certain standards and that if the standards are not maintained, public confidence in the independence and trustworthiness of judicial officers will inevitably erode and the administration of justice will be undermined. The Guide refers to the importance of impartiality, judicial independence, integrity and personal behaviour. In the Guide's introduction, there is a note that some judicial officers adopt what is described as a 'monastic' lifestyle, believing that the less they are involved in non-judicial activities, the less likely they are to put at risk respect for the judiciary. The preferred position is that judicial officers be involved in the community in which they live.

18 (1952) 52 SR NSW 137

19 Australian Institute of Judicial Administration Inc, Guide to Judicial Conduct (3 $3^{\text {rd }}$ ed, November 2017). 
U T S

e PRES S
There is no doubt in my mind that life as a magistrate who lives and works in the city differs from life as a magistrate who lives and works in a rural area. In my short time as a city magistrate, I encountered one accused I knew. He was a friend. He wanted to plead guilty to a minor parking offence. Everyone seemed happy when I sent the case to a magistrate sitting in a courtroom 50 metres away. Upon appointment to the Inverell circuit in 1985, I was in a situation where I had never been to the town before and knew nobody in the town (population about 10,000). I did not adopt a 'monastic' lifestyle and by the time I had been there for two or three years, I knew quite a few people. Acquaintances occasionally appeared before me, most wanting to plead guilty to a traffic offence. The practice I adopted in such cases was one which was close to the practice referred to in the Guide: I would indicate that I knew the accused, would outline the circumstances in which I knew him or her, would indicate the relationship was not so close as to require me of my own volition to disqualify myself and then seek the views of the prosecution and defence. The prosecution and defence would invariably indicate no application to disqualify would be made and I would then hear the case. The Guide points out that a personal friendship is a compelling reason for disqualification but friendship should be distinguished from acquaintanceship, which might be a reason for disqualification. All of that sounds straightforward and easy but there were difficult decisions to be made. It seemed unfair to impose serious inconvenience upon a person purely because they knew me. A city magistrate could send the case next door, as I had done with my friend who had committed a parking offence. As the Magistrate sitting at Inverell, I would have to adjourn the case to another day at another court 200 kilometres away or have the case adjourned to a later date at Inverell being a date upon which I would not be sitting. Such a decision imposed a significant additional burden upon an accused. He or she had to take another day off work, legal costs could be an issue and the accused would have to endure a further period of wondering what would happen.

Similar problems arose occasionally with witnesses in contested cases and the consequences could be significant. Usually, the issue was resolved satisfactorily as I have outlined above. Sometimes, it was a matter of balance. My next-door neighbours were the proprietors of a department store in Inverell and were friends but not close friends. The store was burgled twice when I was the circuit magistrate. On each occasion, one neighbour was to give evidence to the effect that the burglary had taken place and that certain property had been stolen. The defence wished to ask a few questions but the evidence was not controversial. There was no application for me to disqualify myself and I heard each case after disclosing my relationship with the parties. Another matter emphasised the significance of the problem. A contested case was coming to its end. The last defence witness was called. He was a close friend. His evidence was controversial and indications were that his account would be different to that of the prosecution witnesses. I had no alternative but to disqualify myself of my own volition, requiring the parties to start the cases again on some other day when I was not sitting. Such a problem rarely occurs in a trial in the District or Supreme Court in a rural area because the jury is told before evidence is taken who the witnesses will be and jurors are asked to identify any potential problem.

Prior to my appointment to the bench, I was an enthusiastic cricketer and golfer. I continued to play both sports after my appointment. I was appointed to the Inverell circuit at the end of the 1984/1985 cricket season. I joined the local golf club, playing on most weekends that winter. I joined a cricket club the following season and played for nearly ten years, sometimes representing the town in inter-district matches. I was also involved in the sport in an administrative capacity and was secretary and treasurer of the local association for about a 
U T S

e PRES S decade. In those capacities, I met a lot of local residents. Quite a few appeared in court. The Guide refers to social and recreational activities:

[T] here is such a wide range of social and recreational activities in which a judge may wish to engage that it is not possible to do more than suggest some guidelines. Judges should themselves assess whether the community may regard a judge's participation in certain activities as inappropriate. In cases of doubt it is better to err on the side of caution.

I suppose I could have decided not to play golf or cricket to avoid potential problems, something that would not cross the mind of a magistrate living in an urban centre, but I never regretted my decision.

An amusing incident occurred in my second cricket game in Inverell. I knew nobody in the opposing team. I went to the crease at the fall of a wicket, took guard and looked up to see the bowler glowering at me and pointing to the ball. He oozed menace. He looked vaguely familiar. I walked down to my fellow batsman and said 'do you know this bloke?' 'Yes', he replied 'and so should you, he appeared before you last week and I have heard he wasn't very happy with the result'. The first ball I received went over my head, landed somewhere near the wicketkeeper's feet and on to the fence for four sundries.

Some cases which came before me involved a subject which I knew little or nothing about. This was particularly so with civil litigation. Topics such as the quality of grain, a comparison of different hydraulic equipment and the proper way to install a windmill are a few that come to mind. In relation to criminal prosecutions, I encountered, as outlined, cases of stock theft and cases in which a landholder had allegedly failed to rid his or her property of pests, such as rabbits, or noxious weeds, such as blackberries. I found that a lack of knowledge of a particular subject was not a major problem. Cases in which the judicial officer does not know of the subject are encountered in all jurisdictions and all geographical areas and, providing the judicial officer expresses his or her lack of familiarity with the topic (or at least does not pretend to show familiarity with the topic), the judicial officer will invariably receive assistance from legal representatives and witnesses.

\section{Conclusion}

Law enforcement officers have infinitely more tools at their disposal than they did when I became a legal clerk in the 1960s. Legislation has regulated how some technology is used and how some law enforcement procedures are utilised. Early in my career, I instructed Counsel appearing for Keith Kenneth Keillor. Mr Keillor, a habitual criminal whose nickname was the Jitterbug Kid, was alleged to have told Paul Mifsud and Paul Attard how to make and detonate a bomb, which they used to blow up Joseph Borg, the owner of numerous brothels in inner Sydney. The evidence against Mr Keillor was an alleged admission. Two police officers swore that Mr Keillor agreed to be interviewed about the matter, that a record of the interview was typed and that $\mathrm{Mr}$ Keillor agreed he had shown the co-accused how to make and detonate the bomb. The officers indicated that $\mathrm{Mr}$ Keillor was invited to sign the record of the interview but declined to do so. Mr Keillor denied having any conversation of relevance with the officers. $\mathrm{He}$ was convicted. The case had quite an impact upon me. Had Mr Keillor made an admission or not? If he had, he deserved the heavy sentence imposed upon him. If he had not, he was the subject of a dreadful miscarriage of justice. By the 1980s, interviews between police officers and suspects were usually required to be electronically recorded. The new system was a boon 
U T S

e PRES S to honest police officers, to accused and to courts. Conversations were rarely disputed, hours of evidence relating to the admissibility of disputed confessions were eliminated and the court had an accurate account of conversations.

Video machines are now in all highway patrol vehicles. Technology has enabled law enforcement officers to capture much evidence from telephone and social media exchanges. DNA science was the greatest breakthrough in the personal identification field since fingerprinting. Video surveillance cameras provided evidence crucial to many investigations. Two notorious cases demonstrate the importance of modern technology. Melbourne woman Jill Meagher left a social function one night and her body was found some time later. She had been murdered. Images from a video surveillance camera above a shop showed Ms Meagher walking past the shop and, a short time later, a man walking in the same direction. His image was recognised and he was later convicted of the murder. Retired Federal Court Judge Marcus Einfeld was the owner of a car, the driver of which had committed a speeding offence. The offence was detected by a speed camera. Mr Einfeld defended the case and gave evidence he was not the driver. A subsequent police investigation ascertained his whereabouts at various times by using technology relating to his telephone and credit card. It was conclusively established that he had been driving the vehicle.

The science relating to DNA is universally accepted but, like all expert evidence, DNA evidence should never be accepted without scrutiny. DNA can be transferred. When two people shake hands, there is a likelihood that the DNA of each will be found on the other.

It is common today to see females in a court room. Nobody would blink an eye if they walked into a Local Court anywhere in the state and saw a female magistrate, a female police prosecutor, a female defence solicitor and a female court officer. Nobody would have seen that in the 1960s. The first female magistrate in NSW was Margaret Sleeman, appointed in July 1970. The first female police prosecutors were Barbara Galvin and Jacqueline Milledge (now a magistrate), who were appointed in 1974. Very few women studied law in those days. There were 12 females and 191 males in my graduating class. Most law graduates now are women. The sky has not fallen in. It is interesting to note that in a recent decision which engendered controversy, a District Court Judge discharged a jury of 12 males as being unrepresentative of the community. Again, that was not something that would have happened in the 1960s. Jurors were invariably men. A woman could not be on the jury roll unless she applied.

Legislation and society's approach to issues of domestic violence and harassment have been revolutionised in the last 50 years. Until well into the 1970 s, a person was a competent but not compellable prosecution witness in cases where the person's domestic partner was his or her domestic partner. In practice, this meant that women rarely gave evidence against an abusive partner. In some cases, the woman was concerned of the consequences to her partner and the family if there was a conviction but, usually, the woman had been threatened with further violence if she gave evidence. Police officers would disparagingly refer to these cases as 'domestics' as they knew that, despite how diligently a case was prepared, it was likely that the principal witness would either not attend or would arrive and say she would not be giving evidence. Spouses are now compellable witnesses and are supported when at court. In addition, physical evidence can be compelling in such cases. An image of the victim immediately after an alleged assault can be a very important piece of evidence. 
U T S

e P R E S S
The battle against crime will never be won for reasons which I have outlined earlier in this paper. Modern technology, however, can greatly increase the prospects of apprehension and this will deter persons who might otherwise commit a crime.

\section{Bibliography}

\section{ARTICLES/BOOKS/REPORTS}

'Charges Made for Cattle Theft', The Land (7 April 2016)

'Grazier Says Cattle Duffing Case Misleading', ABC Nerws (ABC TV, 15 August 2012)

'Long Complex Investigation Leads to Cattle Duffing', (Courier-Mail 25 May 2012

Australian Institute of Judicial Administration Inc, Guide to Judicial Conduct ( $3^{\text {rd }}$ ed, November 2017)

Drabsch, Talina, A Statistical Snapshot of Crime and Justice in New South Wales (NSW Parliamentary

Library Research Centre, 2010)

Guideline Judgement on High Range PCA 200461 NSWLR 305

Nolan, Tanya, 'Cattle-Duffing Ring Uncovered, PM (ABC Radio National, 25 June 2004)

NSW Bureau of Crime Statistics and Research, Issue Paper 96 (August 2014)

NSW Centre for Road Safety, Road Crash Fatality Rates, 1908-2013 https://roadsafety.transport.nsw.gov. au/statistics/fatality_rates_1908_2013.pdf

Palmer, Mick, Report on illegal fishing for commercial gain or profit in NSW (Department of Primary Industries, 2004) (Palmer Report) <http://www.fisheries.nsw.gov.au/com/pdf/Black-Market-Report.pdf〉

Radelet, M, and T Lacock, 'Do Executions Lower Homicide Rates? The Views of Leading

Criminologists' (2009) 99 Journal of Criminal Law and Criminology 489

Woods, GD, A History of Criminal Law in New South Wales: The Colonial Period 1788-1900 (Federation

Press, vol 1, 2002)

\section{CASES}

Chamberlain v $R$ (1984) 58 ALJR 133

Dudley \& Ors v Dept of Primary Industries and Regions \& Anor (2016) SASC 144

Karpany and anor v Dietman (2013) HCA 47

$R v$ Lachlan 2015 NSWCCA 178

$R v$ Keenan (1994) 76 A Crim R 374

King v Tait (1952) 52 SR NSW 137

DPP $v$ MS DC of VIC (20.2.2015)

DPP v Van Nguyen DC of VIC (12.4.2016)

\section{LEGISLATION}

Bail Act 2001 (NSW)

Crimes (Appeal and Review) Act 2001 (NSW)

Crimes Act 1900 (NSW) 
U T S

e PRESS
Criminal Code Act 1995 (Cth)

Firearms Act 1996 (NSW) s 24.

Native Title Act 1993 (Cth)

Rural Lands Protection Act 1998 (NSW) 